\title{
Hardness of water analysis at the Grotowice intake situated near Opole
}

\author{
Iwona Klosok-Bazan ${ }^{1,{ }^{*}}$, Mateusz Filipowski ${ }^{2}$, and Michat Stojak $^{2}$ \\ ${ }^{1}$ Opole University of Technology, Mechanical Department, 45-271 Opole, Mikolajczyka 5 St., Poland \\ ${ }^{2}$ Wodociągi i Kanalizacja Sp. z o.o. w Opolu, Opole, 45-222 Oleska 64 St., Poland
}

\begin{abstract}
The determination of raw water hardness subsequently treated and used for domestic water supplies is a useful parameter to characterize the present total dissolved solids as well as for calculation dosages for lime-soda softening application. Because water hardness concentrations have not been proven to be health related, the final achieved level is mainly an economic function. To identify existing trends, the changes in water hardness in Grotowice intake for the years 19992017 have been analysed. The obtained results indicate clearly that the water hardness in three wells shows a slight downward trend, but on the other hand, one trend is rising in another direction.
\end{abstract}

\section{Introduction}

Hardness is one of the most noticeable indicators of water quality in the tap. This feature is treated by many customers as a treat to health due to more and more repeated but not proved thesis that hard water results is creation of renal calculi. Meanwhile, as the results of research conducted by the World Health Organisation show [1], both elements which cause the hardness i.e. calcium and magnesium, have a positive impact on human health and their deficit in drinking water may result in electrolyte imbalance. Water hardness is not regulated in the EU law. Under the Polish regulations, hardness of drinking water should be between 60-500 $\mathrm{CaCO}_{3} / \mathrm{dm}^{3}$, while water which is fully in compliance with the Regulation of the Minister of Health on quality of water intended for drinking by people may be not accepted by customers [2] due to excessive precipitation of sediments during its heating process and cooking. Depending on the spring quality, water which used by 4 members family can cause precipitation of even $70 \mathrm{~kg}$ of scale during the year. The amount of precipitated scale is not always proportional to the calcium and magnesium concentration. Precipitation of scale and sediments from water is connected with the so-called temporary hardness i.e. hardness caused by the presence of dissolved salts, mainly hydrogencarbonates which are precipitated during the heating. High carbonate hardness results in many operating problems in the waterworks system as well as in terms of recipients [3-15].

Decrease of calcium carbonate precipitation tendency as a result of water heating is technologically subject to decrease of alkalinity. It is the declination of alkalinity, i.e. decrease of $\mathrm{HCO}_{3}$ anions which influences the decline of the amount of sediments precipitated from the water, however it is not without influence on metal element of waterworks system and internal installations. Therefore, while considering the possibility of introducing water softening systems, it is important to be aware of the negative effects of such actions, manifested in an increase in water aggressiveness level [2,7]. Meanwhile, the water in the tap should be stable. Langelier Index $\left(\mathrm{I}_{\mathrm{L}}\right)$ and Ryznera Index $\left(\mathrm{I}_{\mathrm{R}}\right)$ are often used to evaluate water stability. Unfortunately, these indices allow mostly for comparison of corrosivity of various waters [7,12] and, first and foremost, rough estimation of aggressive carbon dioxide concentration. Meanwhile, water stability is determined on the basis of aggressive carbon dioxide (stable water cannot contain aggressive carbon dioxide $\mathrm{CO}_{2}$ ). Stability criterion is determined by water reaction in the state of $\mathrm{pH}_{\mathrm{S}}$ saturation. Stable water is water which neither dissolves nor precipitates calcium carbonate. Water is stable when $I_{L} e$ is equal to 0 , which suggests that water is not aggressive and has no tendency to create protective $\mathrm{CaCO}_{3}$ layers. When $\mathrm{I}_{\mathrm{L}}$ is below 0 , water is unsaturated and has aggressive properties but when $\mathrm{I}_{\mathrm{L}}$ is higher than 0 , water has a tendency to form $\mathrm{CaCO}_{3}$ sediments but it is not aggressive [16]. Taking the abovementioned into consideration, making proper decision regarding whether and with what methods the water extracted from the intake must be softened is a substantially complex problem. Analysing the available literature [17-20] on the use of water softeners, the precipitation methods using various types of reactors are most commonly used in drinking water supply systems. Application of such a technology requires incurring significant investment expenditures and production of water will require high operating expenses. In consequence, it will induce an increase of price of water delivered to the recipients. However, when the hardness level is "dangerously" close to the level of $500 \mathrm{mg} \mathrm{CaCO} / \mathrm{dm}^{3}$, the investment

Corresponding author: i.klosok-bazan@po.opole.pl 
becomes inevitable. The authors of this work, on the basis of available archival data, decided to analyse changes of the water hardness level, the intake of which is in Grotowice near Opole, to establish the existing tendencies. A significant increase tendency will mean the necessity of inclusion of a new technological system in the investment plans which will serve as a water softener.

\section{Description of research area}

Grotowice water intake uses underground water from the Main Underground Water Reservoir GZWP 333. The area of intake location is a fragment of the Opole Plain. Carboniferous, Permian, Triassic, Cretaceous, Tertiary and Quaternary rocks are part of the geological structure of the described area. The underground reservoir is created by formations of inferior and medial buntsandstein, röt formation and muschelkalk. Currently, the intake includes 4 wells marked as $1 \mathrm{~A}, 1 \mathrm{~B}, 3 \mathrm{~B}$ and 6B. Wells $1 \mathrm{~B}$ and 6B have been functioning since 1995 , and $3 \mathrm{~B}$ and $1 \mathrm{~A}$ since 2008 (Fig. 1).

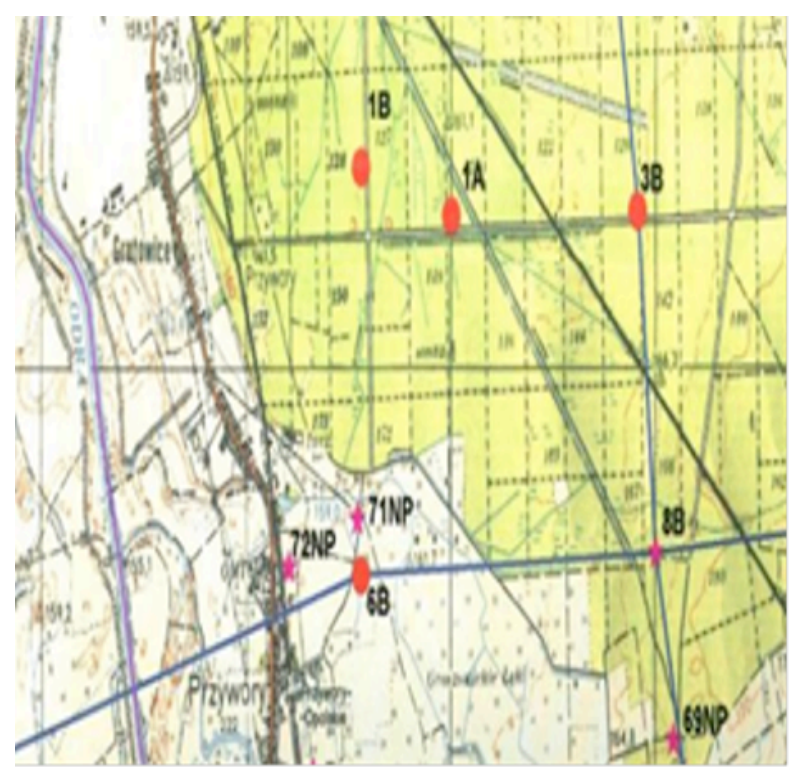

Fig. 1. Wells location in Grotowice intake.

Wells $1 \mathrm{~b}$ and $6 \mathrm{~b}$ have been used continuously and well 3B is included in case of higher demands. Well 1A is an emergency well. Raw water is a mixture of water from particular wells with a significant share of water from wells $1 \mathrm{~B}$ and $6 \mathrm{~B}$. Raw water pumped from Grotowice intake is delivered to the water supply network without treatment, however for the purpose of bacteriological protection, the water is disinfected using sodium hypochlorite. This water has very good quality, neutral reaction of ca. 7.5 and alkalinity ranging from 4.2 to $5.4 \mathrm{mval} / \mathrm{dm}^{3}$. Water is characterised by low concentration of iron, it does not need application of deironing processes. Unfortunately, water analyses indicate presence of nitrogen compounds the concentration of which, in the analysed period, reached values in the range of: $0.01-0.061 \mathrm{mgNH}_{4}{ }^{+} / \mathrm{dm}^{3} ; 2-23$
$\mathrm{mgNO}_{3} / \mathrm{dm}^{3}$ and $0-0,024 \mathrm{mgNO}_{2} / \mathrm{dm}^{3}$. The characteristic feature of Grotowice water is its hardness reaching 440 $\mathrm{mg} \mathrm{CaCO} / \mathrm{dm}^{3}$. Relatively high hardness connected with the lack of thermal stability makes this parameter cause the highest number of customers' complaints. The water has tendency to precipitate sediments when heated [17]. The fact that the source is subject to strong anthropogenic impact caused by the active calcium excavations the exploitation of which has a significant impact on the changes of the level of water surface in the reservoir, is important from the point of view of the analysis of water hardness changes at the Grotowice intake. Both the quality of raw water as well as the quality of water in the particular wells is systematically monitored by Wodociągi and Kanalizacje Sp z.o.o in Opole.

\section{Materials and methods}

The quality of raw water in Grotowice intake is affected by the water parameters of the particular intake wells. In order to determine the tendency of changes, water quality in all exploited wells of Grotowice was analysed. Available archival data regarding analyses of water hardness were collected. The first stage of the analysis included determination of the characteristic concentrations for the analysed parameter: minimum, maximum and average values as well as standard variations. Potential seasonal changes of water hardness levels were analysed at the next stage of the paper by means of analysis of average concentration in the particular months in each of the analysed periods. In order to calculate the average hardness levels, the harmonic mean calculations were applied as, according to the authors of this article, it fits this type of analysis well due to the fact that the analysed data are relative values with identical signs. Then, by means of application of harmonic mean, average annual level of water hardness in the particular wells was calculated and the obtained data were used to specify the trend function. Graphical analysis was applied, then it was examined whether the implementation of dependent variable does not negate the dynamic properties of the function adopted initially as a result of the analysis. The available results of water quality analyses conducted by Wodociągi i Kanalizacje Sp. z o.o. in Opole were used as source data. Data obtained in 1997-2017 were interpreted for well 1B and 6B, and data from 2009 were interpreted for well $3 \mathrm{~B}$ and $1 \mathrm{~A}$.

\section{Results and discussion}

Water hardness in the particular wells of Grotowice intake is subject to fluctuations. Those fluctuations are of temporary nature and do not show any significant identifiable tendencies, they appear unexpectedly and the reasons for which they occur are difficult to identify. Surely, it can be said that they are not connected with the changes of water volume collected from the analysed wells (Fig. 2-Fig. 4). 


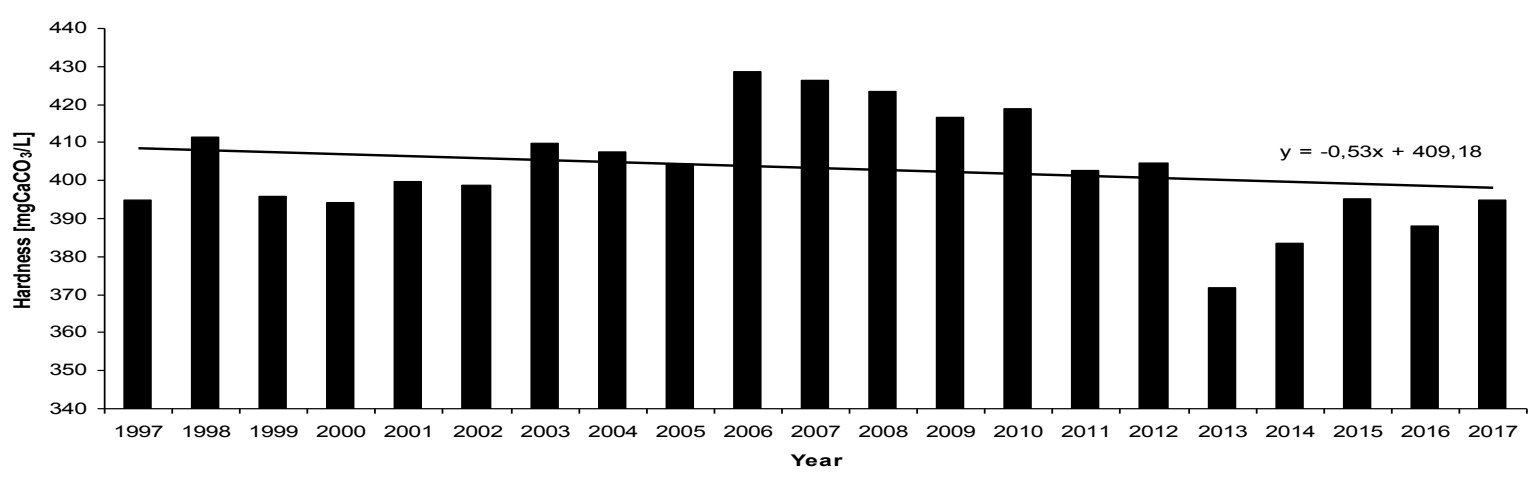

Fig. 2. Average hardness in years1997 -2017 in 1 B Well, with trend function.

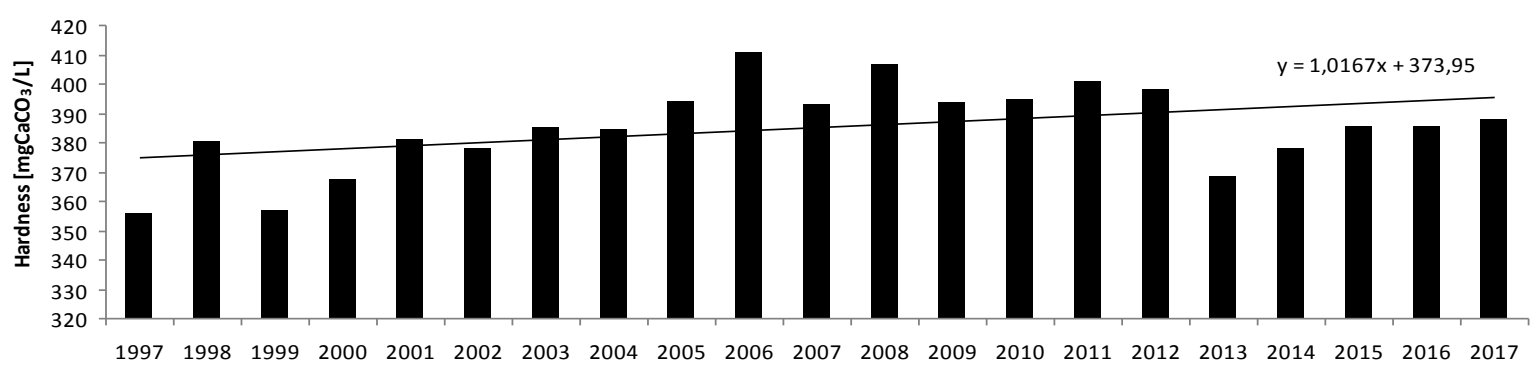

Year

Fig. 3. Average hardness in years $1997-2017$ in 6 B Well, with trend function.

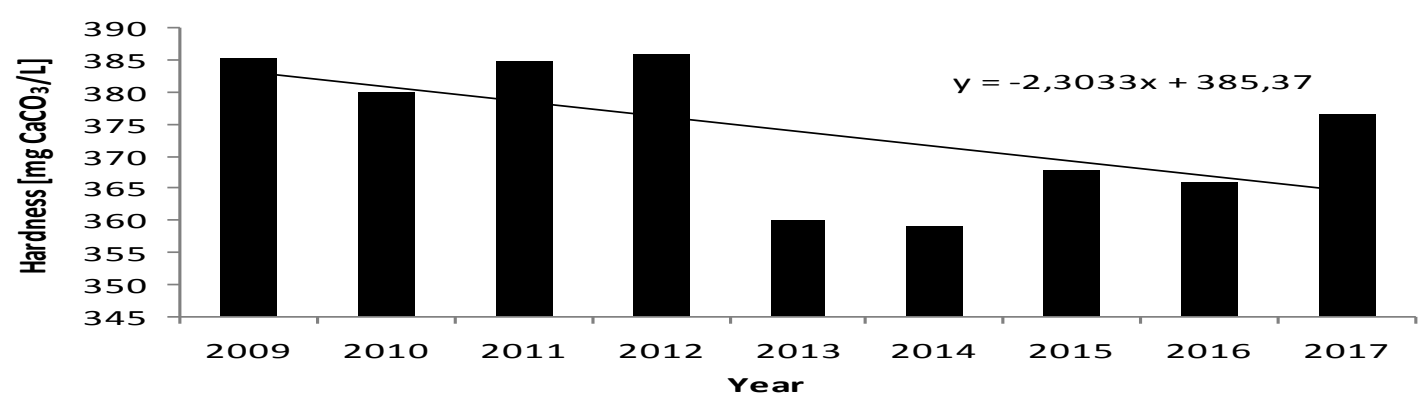

Fig. 4. Average hardness in years 2009 - 2017 in 3 B Well, with trend function.

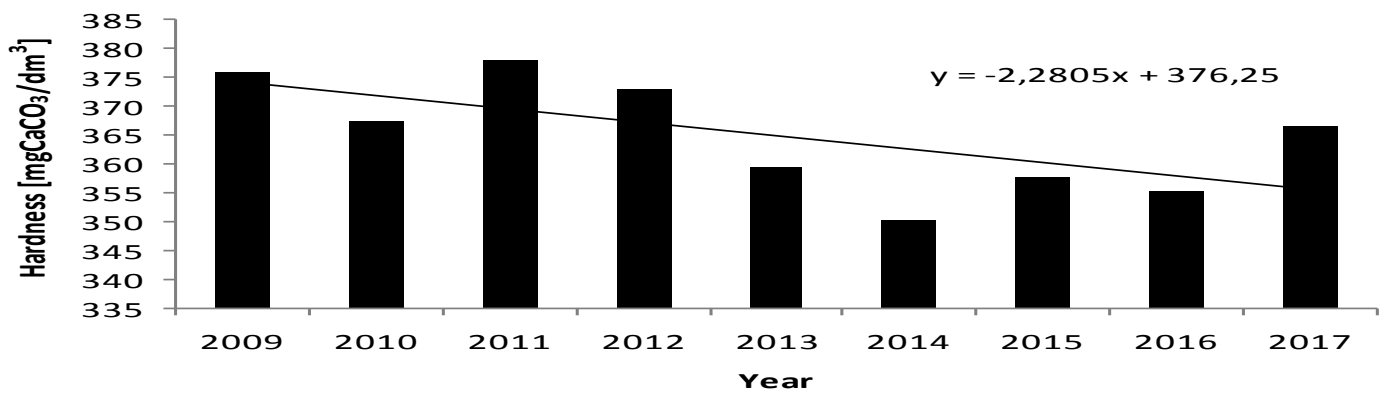

Fig. 5. Average hardness in years 2009 - 2017 in 1 A Well, with trend function. 
The highest level of hardness for well $1 \mathrm{~B}$ was recorded in 2008, and the highest average hardness throughout the year was detected in 2006.

An analysis of hardness level in the particular months of the period from 1997 to 2017 did not reveal any seasonal change tendencies. The determined trend line for the average annual values shows a slight decline (Fig. 2). The well in which the highest concentration of the analysed parameter was found is well 6B. Maximum hardness level of $535 \mathrm{mg} \mathrm{CaCO} 3 / \mathrm{dm}^{3}$ was recorded in June of 2008, however, analyses preceding this high level were respectively 402 and $460 \mathrm{CaCO}_{3} / \mathrm{dm}^{3}$ with a monthly average of $420 \mathrm{CaCO}_{3} / \mathrm{dm}^{3}$. In case of well $6 \mathrm{~B}$, the trend line for the average annual hardness value is, in its nature, an increasing function. This is the only well in which the calculated trend function is increasing (Fig. 3). Data regarding average annual level of water hardness, together with the marked trend line are presented in (Fig. 4). Similarly to the case of well 1B, the determined trade line takes the form of a decreasing function. The highest fluctuations of the monthly average value of the analysed parameter were detected in well $1 \mathrm{~A}$; they are between $332-398 \mathrm{mg} \mathrm{CaCO} / \mathrm{dm}^{3}$. This is probably due to the fact that the wells are included in operation in a cyclic manner. With the current level of production, this well is launched mainly during water collection for monitoring purposes. The line for wells $1 \mathrm{~B}$ and $3 \mathrm{~B}$, determined for the average annual hardness levels in well $1 \mathrm{~A}$, is decreasing in nature.

\section{Conclusions}

The statistical analysis based on interpretation of actual archival data has shown that the water hardness level of three wells of Grotowice intake (1B, 3B and 1A) show a slightly decreasing tendency, but water hardness in well $6 \mathrm{~B}$ shows an increasing tendency. Investigating the results of the particular analyses performed between 1997-2017, one should note the high variability of values obtained in the particular determined points. Taking into consideration the fact that the laboratory where the analyses were performed holds an accreditation, the argument of significant measurement errors was rejected. Therefore, the water in the source shows significant variability of the water hardness parameter and it must be emphasised that those fluctuations occur with short intervals. The thesis connected with the influence of the method of mining of the calcium minerals on the variability of collected water was not confirmed and requires detailed analyses.

\section{References}

1. Hardness in drinking-water. Background document for development of WHO Guidelines for Drinkingwater Quality. World Health Organization, 2011

2. W. Sawiniak, I. Klosok-Bazan, J. Szczepankiewic, Instal 12, (2014)

3. M. Mons, J. Van Dijk, D. Gatel, Global Water Res. Coalition, London, (2007)
4. J. Nawrocki, S. Biłozor, Uzdatnianie wody Procesy chemiczne i biologiczne (PWN Poznań 2000)

5. I. Klosok-Bazan, Ochr. Sr. 36, 2 (2014)

6. I. Zimoch, Ochr. Sr. 30, 3 (2008)

7. K. Kuś, F. Piechurski, D. Okoń,. Ochr. Sr. 51, 4 (1993)

8. Ł. Weber, Techn. wody, 21 (2013)

9. I. Zimoch, Ochr. Sr. 34, 4 (2012)

10. B. Godskesen, M. Hauschild, et al., J. Envir. Manag. 105 (2012)

11. I. Zimoch, E. Szymura, K. Moraczewska-Majkut. Desalin. Water Treat. 57, 3 (2016)

12. J. Hoek, B. Dijkman, et al., Water Sci. Technol. 39, 5 (1999)

13. I. Zimoch, Ochr. Sr. 29, 4 (2007)

14. M. Bożym, I. Kłosok-Bazan, M. Wzorek, Pol. J. Environ. Stud. 27, 3 (2018)

15. M. Pawlita-Posmyk, M. Wzorek, Chemik, 70, 10, (2016)

16. J. Hofman, O. Kramer, P. Van Der Hoek, Water 21, (2007)

17. M. Mons, J. Van Dijk, Drinking water hardness: Reasons and Criteria for Softening and Conditioning of Drinking Water, Global Water Research Coalition, London, (2007)

18. B. Van der Bruggen, H. Goossens, P. Everard, P. Stemge'e, W. Rogge, J. Environ. Manage. 91, (2009)

19. J. Boguniewicz-Zablocka, I. Klosok-Bazan, E. Podgorni, Forum on Current issues in water treatment and water distribution, Gliwice, (2016)

20. I. Zimoch, E. Szymura, K. Moraczewska-Majkut. Przem. Chem. 94, 2 (2015) 